\title{
TEACHING STUDENT'S READING COMPREHENSION USING TWO STAY TWO STRAY TECHNIQUE
}

\author{
Wasilah Sa'adah ${ }^{1}$, Fraditha Pinasty Sanjaya ${ }^{2}$ \\ IKIP Siliwangi \\ ${ }^{1}$ wasilahsaadah18@gmail.com, ${ }^{2}$ fraditha.pinasty@gmail.com,
}

\begin{abstract}
Reading comprehension is a important part in reading process. In learning English, students may face some difficulties in learning reading, even though they are students of Senior High School. Therefore the teacher should teach them by appropriate technique to solve their difficulties. This research was conducted to find out the effectiveness of using two stay two stray technique in teaching student's reading comprehension. It was conducted by quantitative research design with pre experimental one group pretest posttest design involving 32 of tenth grade students of Senior High School in Cianjur. The instrument used in this research was test (pretestposttest) which given before and after treatment. The result of data analysis in this research shows the $t_{\text {score }}$ is 25.106, it is higher than $\mathrm{t}_{\text {table }}$ with degree of freedom (df) 31 and level of significant (2-tailed) at $5 \%(0.05)$ which has value of 2.039 . Because $t_{\text {score }}>t_{\text {table }}(25.106>2.039)$, then Ha is accepted. In other words, there is the effectiveness of using two stay two stray technique in teaching student's reading comprehension.
\end{abstract}

Keywords: Reading Comprehension, Two Stay Two Stray Technique

\section{INTRODUCTION}

The In learning english, students should master four skills of language, namely listening, speaking, reading and writing. Reading is one of skills that can give information for the students as the reader from the text. According to Grabe and Stoller (2002:9) "Reading is the ability to draw meaning from the printed page and interpret this infromation appropriately". To interpret what they read, the reader should comprehend the contain of the text firstly. Comprehension is a part of reading. It may also be said as the core point of reading process. According to Snow $(2002: 11)$ "Reading comprehension as the process simultaneously extracting and constructing meaning through interaction and involvment with writen language.

Furthermore, difficulties of learning reading comprehension can be faced by students, includes Senior High School Students. The difficulties above such as, the students can not understand the language feature and purpose of the text, also they difficult to make conlusion of reading text. Those difficulties can be solved by appropriate teaching methods that should be applied by the teacher as facilitator of their students to improve student's reading comprehension. One of various methods that can be applied by teacher is cooperative learning. Bowering (et al,2007) says that "Cooperative learning is a general teaching method where students work together in face to face interaction without direct teacher supervision to achieve common goal". There are many techniques of cooperative learning method that can be used by teacher, one of them is Two Stay Two Stray (TSTS). Huda (2013:140) says that Two Stay Two Stray is a cooperative learning that developed by Spencer Kagan (1990) which contents four members of each group and make them can share the information to other groups.

Based on the explanation above, the writer conducted a research at the tenth grade students of Senior High School in Cianjur entitled Teaching Student's Reading Comprehension Using 
Two Stay Two Stray Technique with objective of the research is to find out the effectiveness of the use two stay two stray technique in teaching student's reading comprehension.

\section{METHOD}

In this research the writer used quantitative research design which consists of numeric data and statistical method. According to Bungin (2006:50) "Quantutative research design stresses the analysis to the numerical data that was processed by statistical method". Then the research method used in this research was pre experimental one group pretest posttest because the writer used only one class as the sample. According to Arikunto (2013:124), the design of pre experimental one group pretest posttest can be seen as follows:

$$
\begin{array}{lll}
\mathbf{0}_{1} & \mathbf{X} & \mathbf{0}_{2}
\end{array}
$$

Figure 1. Design of pre experimental one group pretest and posttest design

From the design of research above, there were three steps in conducting pre experimental one group pretest posttest design:

1. The writer gives students test before treatment (pretest) to find out reading comprehension of the tenth grade before being taught by using Two Stay Two Stray. It is signed by $0_{1}$.

2. The writer applies the treatment, it means that the writer uses two stay two stray technique in teaching reading comprehension. It is signed by X.

3. The writer gives second test after treatment (posttest) to measure reading comprehension of the tenth grade after being taught by using Two Stay Two Stray. It is signed by $\mathrm{T} 2$.

Furthernore, Arikunto (2013: 173) says that "population is total number of research respondent". The population of this research was tenth grade students of Senior High School in Cianjur. In selecting sample of the research, the writer used purposive sampling technique, then its result was tenth grade students of class X IPS 1. Instrument used was multiple choice test which given twice as pretest and posttest. The pretest was given to students before treatment, then the posttest was given after treatment. In scoring the result of the test, the writer used reading scoring according to Khoerudin (2016:198) as in the following:

$$
\mathrm{B}=\frac{N \times 100}{n}
$$

Note :

$\mathrm{B}=$ Student's score

$\mathrm{N}=$ Right answer

$100=$ maximum score

$\mathrm{n}=$ total items 
In collecting data, the writer conducted three steps, they were pretest, treatment and posttest. After the research data got by writer, the writer analyzed it using IBM SPSS version 21 then analyzed it into descriptive statistics, tests of normallity and t-test.

\section{RESULTS AND DISCUSSION}

\section{Results}

The result of research data includes score of pretest and posttest showed as in the following:

Table 1. The score of pretest and posttest

\begin{tabular}{|c|c|c|c|}
\hline No & Respondents & Pretest & Posttest \\
\hline 1 & Student 1 & 70 & 85 \\
\hline 2 & Student 2 & 55 & 75 \\
\hline 3 & Student 3 & 75 & 95 \\
\hline 4 & Student 4 & 60 & 80 \\
\hline 5 & Student 5 & 80 & 90 \\
\hline 6 & Student 6 & 75 & 90 \\
\hline 7 & Student 7 & 60 & 85 \\
\hline 8 & Student 8 & 55 & 85 \\
\hline 9 & Student 9 & 50 & 70 \\
\hline 10 & Student 10 & 70 & 85 \\
\hline 11 & Student 11 & 60 & 80 \\
\hline 12 & Student 12 & 60 & 80 \\
\hline 13 & Student 13 & 75 & 90 \\
\hline 14 & Student 14 & 55 & 75 \\
\hline 15 & Student 15 & 50 & 75 \\
\hline 16 & Student 16 & 60 & 75 \\
\hline 17 & Student 17 & 65 & 85 \\
\hline 18 & Student 18 & 65 & 85 \\
\hline 19 & Student 19 & 60 & 85 \\
\hline 20 & Student 20 & 65 & 80 \\
\hline 21 & Student 21 & 60 & 75 \\
\hline 22 & Student 22 & 65 & 80 \\
\hline 23 & Student 23 & 50 & 70 \\
\hline 24 & Student 24 & 50 & 75 \\
\hline 25 & Student 25 & 60 & 75 \\
\hline 26 & Student 26 & 50 & 70 \\
\hline 27 & Student 27 & 50 & 75 \\
\hline 28 & Student 28 & 80 & 95 \\
\hline 29 & Student 29 & 60 & 80 \\
\hline 30 & Student 30 & 65 & 85 \\
\hline 31 & Student 31 & 60 & 80 \\
\hline 32 & Student 32 & 65 & 70 \\
\hline
\end{tabular}


Based on the research data of pretest anad posttest score above, the writer analyzed the data tinto some steps in the following:

Table 2 Descriptive statistics

\begin{tabular}{|l|l|l|l|l|l|l|}
\hline & N & Minimum & Maximum & Sum & Mean & $\begin{array}{l}\text { Std. } \\
\text { Deviation }\end{array}$ \\
\hline Pre_Test & 32 & 50 & 80 & 1970 & 61,56 & 8,839 \\
Post_Test & 32 & 70 & 95 & 2580 & 80,63 & 7,042 \\
Valid N & 32 & & & & & \\
(listwise) & & & & & & \\
\hline
\end{tabular}

In the table above, it can be seen the lowest and highest score of 32 students. The lowest score of pretest was 50 then posttest was 70 . While the highest score of pretest was 80 and post test was 95. Beside that, the mean score of pretest showed 61,56 while posttest was 80.63. Generally, the table above shows that the posttest scores are higher than pretest.

Table 3. Normallity Test

\begin{tabular}{|l|l|l|l|l|l|l|}
\hline & \multicolumn{3}{|l|}{ Kolmogorov-Smirnov $^{\text {a }}$} & \multicolumn{3}{l|}{ Shapiro-Wilk } \\
\cline { 2 - 7 } & Statistic & Df & Sig. & Statistic & df & Sig. \\
\hline Pre_Test &, 225 & 32 &, 000 &, 910 & 32 &, 011 \\
Post_Test &, 150 & 32 &, 065 &, 912 & 32 &, 013 \\
\hline
\end{tabular}

In accordance with decision of normallity test, the test is stated normally distributed if the value of Sig > 0.05 ( Sig higher than 0.05). Based on the table above, it can be seen in the column shapiro wilk that pretest and postest value Sig. were 0.011 and 0.013 . It means, both of value of Sig $>0.05$. So, the test can be stated normallty distributed.

Table 4. Paired sample t test

\begin{tabular}{|c|c|c|c|c|c|c|c|c|c|}
\hline & \multicolumn{5}{|c|}{ Paired Differences } & \multirow[b]{3}{*}{$\mathrm{t}$} & \multirow[b]{3}{*}{ Df } & \multirow{3}{*}{$\begin{array}{l}\text { Sig. } \\
(2- \\
\text { tailed })\end{array}$} \\
\hline & & \multirow[b]{2}{*}{ Mean } & \multirow{2}{*}{$\begin{array}{l}\text { Std. } \\
\text { Deviation }\end{array}$} & \multirow{2}{*}{$\begin{array}{l}\text { Std. } \\
\text { Error } \\
\text { Mean }\end{array}$} & \multicolumn{2}{|c|}{$\begin{array}{l}95 \% \\
\text { Confidence } \\
\text { Interval of the } \\
\text { Difference }\end{array}$} & & & \\
\hline & & & & & Lower & Upper & & & \\
\hline $\begin{array}{l}\text { Pair } \\
1\end{array}$ & $\begin{array}{l}\text { Pre_Test } \\
- \\
\text { Post_Test }\end{array}$ & $\begin{array}{l}- \\
19,063\end{array}$ & 4,295 & ,759 & $\overline{2}-6,611$ & $\begin{array}{l}- \\
17,514\end{array}$ & $\overline{25,106}$ & 31 & ,000 \\
\hline
\end{tabular}


Based on the table 4 above, we can conclude that the $t_{\text {score }}$ is 25.106 and it is higher than $t$ table with degree of freedom (df) 31 and level of significant (2-tailed) at 5\% (0.05) which has value of 2.039. Because $t_{\text {score }}>t$ table $(25.106>2.039)$, it can be stated that Ho is rejected and Ha is accepted.

\section{Discussion}

Based on the explanation above, it can be seen that mean score of posttest is higher than pretest $\quad(80.63>61.56)$. In other words there is improvement from pretest'score to posttest's score. In addition, the result of $t$ test shows that that $t_{\text {score }}$ is 25.106 , it is higher than $t_{\text {table }}$ with degree of freedom (df) 31 and level of significant (2-tailed) at 5\% (0.05) which has value of 2.039. Because $t$ score $>t$ table $(25.106>2.039)$, it can be stated that Ho is rejected and $\mathrm{Ha}$ is accepted. So, it can be known that the use of two stay two stray technique is effecttive in teaching student's reading comprehension

\section{CONCLUSION}

Based on the result of data anlysis of pretest and posttest, there is significant difference between student's reading comprehension achievement before and after the treatment of two stay two stray teachnique. In the end of result of data analysis conclude that the use of two stay two stray technique is effective in teaching student's reading comprehension. It is proved by result of $t$ test which shows that $t_{\text {score }} 25.106$, it is higher than $t_{\text {table }}$ with degree of freedom (df) 31 (the number of the sample minus 1) and level of significant (2-tailed) at 5\% (0.05) which has value of 2.039 (that is taken from the $\mathrm{t}$-table value). Because $\mathrm{t}_{\text {score }}>\mathrm{t}$ table $(25.106>$ 2.039), it can be stated that Ho in this research is rejected and Ha is accepted. In other words, this research had confirmed that there is effctiveness in teaching student's reading coomprehension using two stay two stray technique.

\section{ACKNOWLEDGMENTS}

This research was supported by IKIP Siliwangi Bandung. We gratefully thank to our colleagues of IKIP Siliwangi Bandung who provided insight and expertise that greatly assisted the research. Then, we would like to thank to our supervisor who always gives guidance in conducting the research. The last, we also thank to anonymous reviewers for their comments on an earlier version of the manuscript, although any errors are our own. 
200 Sa'adah, Sanjaya, Teaching student's reading comprehension...

\section{REFERENCES}

Arikunto,S. (2013). Prosedur Penelitian Satuan Pendidikan Praktek. Jakarta: Renaka

Bowering, e. a. (2007). International Society for Exploring Teaching and Learning Education International Journal of Teaching and Learning in Higher Education.

Bungin, M. B. (2006). Metodologi Penelitian Kuantitatif. Jakarta: Kencana.

Grabe, W. \& S. (2002). Teaching and Researching Reading. Britain: Longman.

Huda, M. (2011). Cooperative Learning. Yogyakarta: Pustaka Belajar.

Khoerudin. (2002). Teknik Penskoran Tes Obyektif Model pilihan Ganda. Jurnal Madaniyah

Snow, C. (2002). Reading for Understanding towards $R \& B$ Program in Reading Comprehension. California: RAND Education. 